\title{
INFLUENCE OF AUXILIARY INTAKE VALVE WITH VARIABLE TIMING ON SPARK IGNITION ENGINE PERFORMANCE
}

\author{
Ahmed, S.A. , Ibrahim, A. M. ${ }^{* *}$ Wassef, F. M. . and \\ Selim, $\boldsymbol{H}$. \\ *: lecture assistant, **: Professor \\ Mechanical Engineering Department, Faculty of Engineering, Assiut \\ University, 71516 Assiut
}

(Received November 22, 2009 Accepted December 30, 2009).

\begin{abstract}
A new variable valve timing strategy based on using an auxiliary valve having a variable timing (VVT) is used in this study. The valve is driven by a new VVT mechanism achieving valve duration and opening angle variations. The auxiliary valve acts as intake valve. Experiments and simulation models are carried out at different loads. The results show improvements in brake thermal efficiency, fuel consumption, volumetric efficiency, residual gas fraction and engine emissions over the whole range of load. Swirl and tumble ratios are decreased.
\end{abstract}

\section{INTRODUCTION}

VVT is a promising feature for automotive engines because it allows optimization of the valve timing over a wide range of engine operating conditions. There are four VVT strategies [1,2]: (1) Phasing only the intake valve. (2) Phasing only the exhaust valve. (3) Phasing the exhaust and the intake valves equally. (4) Phasing the exhaust and the intake valves independently. The first VVT mechanism was built by Alfa Romeo (1985) [3] following strategy (1). It is followed by Toyota mechanism (1990) having the same strategy and features [2].Another mechanisms were carried out by $[4,5,6]$ following the same strategy achieving late closing of intake valve at part loads for reducing pumping losses and improving charging. Parker, P. H. et al $[7,8]$ developed VVT mechanism of Rover K16 engine following strategy (1). It increases volumetric efficiency by $7 \%$ at high speed but it decreases it by $4 \%$ at low speeds. Sellnau, M. et al [9] developed a simulation study on both strategies (1) and (2). The fuel consumption was improved by $9 \%$ in strategy (1) and $1 \%$ in strategy (2). Another VVT mechanism is developed by BMW following strategy (4) and achieving fuel consumption reduction of $3 \%$ at optimum timing [10]. The mechanism reduces fuel consumption and engine emissions in spit of reducing swirl. In this study a new strategy is developed by using VVT mechanism with auxiliary intake valve, while both main intake and exhaust valves having fixed timing.

\section{ORIGINAL ENGINE}

The original engine is a four stroke spark ignition engine which has a bore of $65 \mathrm{~mm}$, a stroke of $100 \mathrm{~mm}$, a compression ratio of 6.6 and engine speed of $1200 \mathrm{rpm}$. The other specifications are mentioned in [11]. Experiments are carried out on the engine at different loads. The loads under considerations are: Full load (1.45 kW), 1.1 kW (3/4 
load), $0.75 \mathbf{~ k W}$ (1/2 load) and $0.4 \mathbf{~ k W}$ (1/4 load). At each load the engine parameters under considerations are: brake power, mass flow rates of air, fuel and fresh charge, volumetric efficiency, brake thermal efficiency and $b s f c$. The one-dimensional simulation model which is described in [11], predicts residual gas fraction, CO concentration based on dry moles, NOx and HC concentrations. Table 1 shows the engine performance parameters at the loads under consideration.

Table 1 Original engine performance parameters at full load and part loads

\begin{tabular}{|l|l|l|l|l|}
\hline Engine parameter & Full load & $1.1 \mathrm{~kW}$ & $0.75 \mathrm{~kW}$ & $0.4 \mathrm{~kW}$ \\
\hline Brake thermal efficiency \% & 16.7 & 15.7 & 12.7 & 8.38 \\
\hline bsfc $(\mathrm{kg} / \mathrm{kW} . \mathrm{h})$ & 0.486 & 0.518 & 0.638 & 0.97 \\
\hline Mass flow rate of air $(\mathrm{kg} / \mathrm{s})$ & $2.49 \mathrm{E}-3$ & $2.15 \mathrm{E}-3$ & $1.88 \mathrm{E}-3$ & $1.61 \mathrm{E}-3$ \\
\hline Mass flow rate of fuel $(\mathrm{kg} / \mathrm{s})$ & $1.96 \mathrm{E}-4$ & $1.58 \mathrm{E}-4$ & $1.33 \mathrm{E}-4$ & $1.08 \mathrm{E}-4$ \\
\hline Equivalence ratio & 1.19 & 1.11 & 1.07 & 1.01 \\
\hline Volumetric efficiency \% & 64.2 & 55.4 & 48.3 & 41.5 \\
\hline Residual gas fraction \% & 9.62 & 10.92 & 12.75 & 14.5 \\
\hline CO concentration \% & 4.86 & 2.95 & 1.88 & 0.61 \\
\hline NO Concentration $(\mathrm{ppm})$ ) & 207 & 462 & 646 & 1035 \\
\hline HC concentration $(\mathrm{ppm})$ & 2633 & 2591 & 2749 & 2625 \\
\hline
\end{tabular}

\section{THEORETICAL MODELS}

Two simulation models are used in this study, one-dimensional simulation model which is described in [11] and three-dimensional simulation model using SST $k-\omega$ turbulence model [12].

\subsection{The VVT Engine Geometry}

It is the same original engine after adding auxiliary intake valve and VVT mechanism for driving it. Elevation, plane and side view of the engine cylinder, valves, intake and exhaust pipes geometries are illustrated in Fig.1 with $x, y$ and $z$ coordinates. Main and auxiliary carburetor throttle valves effective diameters $D_{\text {th main }}$ and $D_{\text {th aux }}$ are calculated according to throttling inclination angles [13]. Input air and fuel mass fractions through main and auxiliary intake valves are calculated using the experimental mass flow rates. The engine geometry are constructed and meshed by Gambit Program. In meshing process, the domain is divided into several parts connected to each others. Main and auxiliary intake pipes, besides exhaust pipe are meshed using Tet/Hybrid-TGrid type of $3 \mathrm{~mm}$ size. Regions upper and below the valves are meshed using Tet/Hybrid-TGrid type of $1 \mathrm{~mm}$ size and the adjacent meshes layers to the valves have a height of $0.5 \mathrm{~mm}$ for good prediction of flow behavior through these regions. Clearance and stroke volumes are meshed by Tet/Hybrid-TGrid type of $3 \mathrm{~mm}$ size. The computational grid is shown in Fig.1. Fluent 6.3.26 code is used as a solver program. 


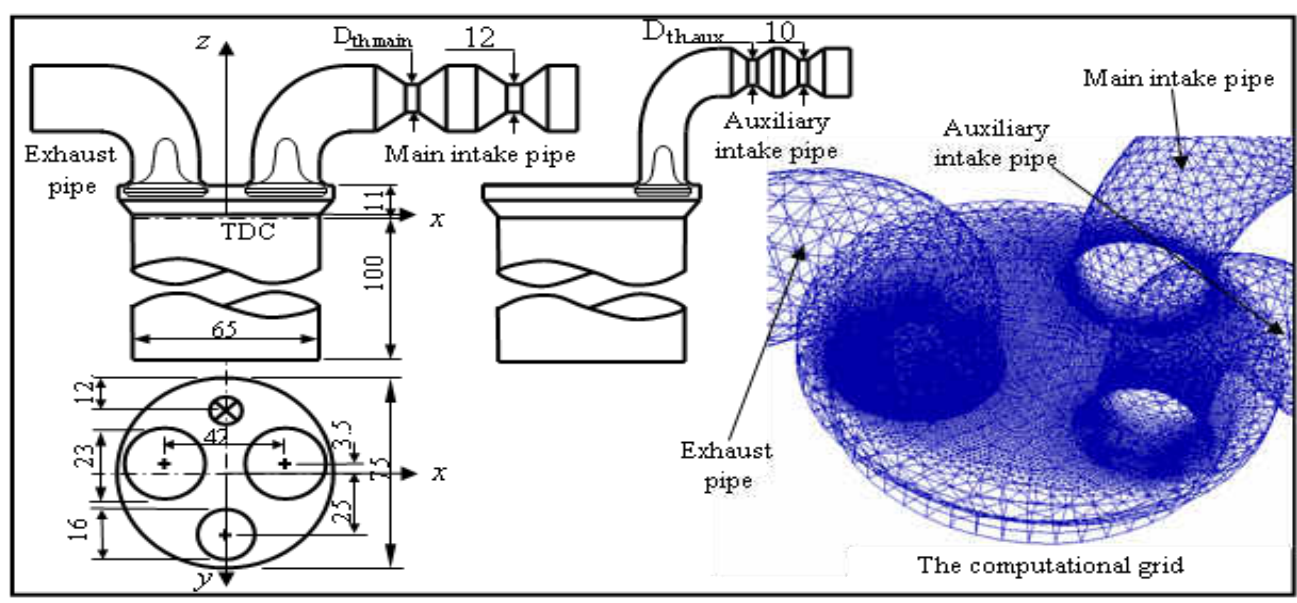

Fig. 1 Elevation, plan and side view of the VVT engine and the computational grid

\subsection{Boundary Conditions and Initial Conditions}

Pressure at main intake pipe entrance, auxiliary intake pipe entrance and exhaust pipe exit is assumed to be $101.3 \mathrm{kPa}$. Fresh charge temperature through main and auxiliary pipes is taken to be $298 \mathrm{~K}$. Auxiliary valve duration of $196{ }^{\circ} \mathrm{CA}$ is used as a case of study for different loads. The auxiliary valve opening angle is varied from $40{ }^{\circ} \mathrm{CA}$ BTDC to $40{ }^{\circ} \mathrm{CA}$ ATDC with $20^{\circ}$ interval. Initial in-cylinder mixture properties (pressure, temperature, specific heats, specific heats ratio, viscosity, thermal conductivity and gas constant) are calculated by the one-dimensional model. The experimental set up is illustrated in [11].

\section{VALIDATION OF THE THREE-DIMNSIONAL MODEL}

Fluent 6.3.26 code provides several models for solving turbulent flow. These are: Standard $k-\varepsilon$, RNG $k-\varepsilon$, Realizable $k-\varepsilon$, Standard $k-\omega$ and SST $k-\omega$. The validity of the present simulation model was evaluated by applying the different turbulence models and comparing their results with the experimental measurements on a similar engine machine shown in Fig. 2 [15]. From Figs 3 to 5, it is obvious that SST $k-\omega$ gives the best agreement with the experimental measurements.

\section{THE VVT ENGINE PERFORMANCE}

Experiments are carried out on the VVT engine at full load, $1.1 \mathrm{~kW}, 0.75 \mathrm{~kW}$ and 0.4 kW with auxiliary valve opening durations: 196, 204, 212, 220, 228, $236{ }^{\circ} \mathrm{CA}$. At each duration, five intake opening angles are used, $40{ }^{\circ} \mathrm{CA}$ BTDC, $20{ }^{\circ} \mathrm{CA}$ BTDC, TDC, 20 ${ }^{\circ} \mathrm{CA}$ ATDC and $40{ }^{\circ} \mathrm{CA}$. These valve opening angles will be denoted in the following figures as $-40^{\circ},-20^{\circ}, 0^{\circ}, 20^{\circ}$ and $40^{\circ} \mathrm{CA}$ respectively. At each condition, the same engine parameters in Sec. 3 are considered. Two variation parameters are used for comparison, $\mathrm{V}_{1}$ and $\mathrm{V} 2$, as follows: 


$$
V_{1} \%=\left(\left(\xi-\xi_{\text {orig }}\right) / \xi_{\text {org }}\right) \times 100
$$

Where: $V_{l}$ is the variation percentage, $\xi$ is the VVT engine parameter under consideration and $\xi_{\text {org }}$ is the same parameters of the original engine under the same load. As the maximum value of each engine parameter does not occur at maximum brake thermal efficiency, another variation percentage $V_{2}$ illustrates the difference between the maximum engine parameter magnitude and its value at maximum brake thermal efficiency. This variation percentage is applied for the VVT engine only. It is defined as follows:

$$
V_{2} \%=\left(\left(\xi_{\eta_{b \max }}-\xi_{\text {max }}\right) / \xi_{\text {max }}\right) \times 100
$$

Where: $\xi_{\max }$ is the engine parameter under consideration and $\xi_{\eta_{b h \max }}$ is the same parameters at maximum brake thermal efficiency. $V_{l}$ and $V_{2}$ are listed in table 2.

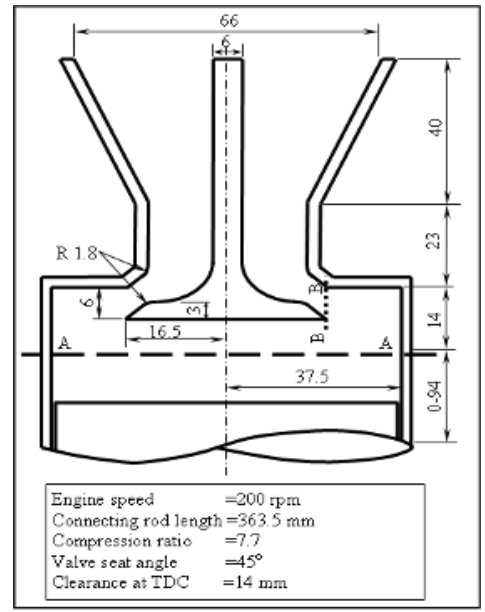

Fig. 2 Schematic diagram of the machine

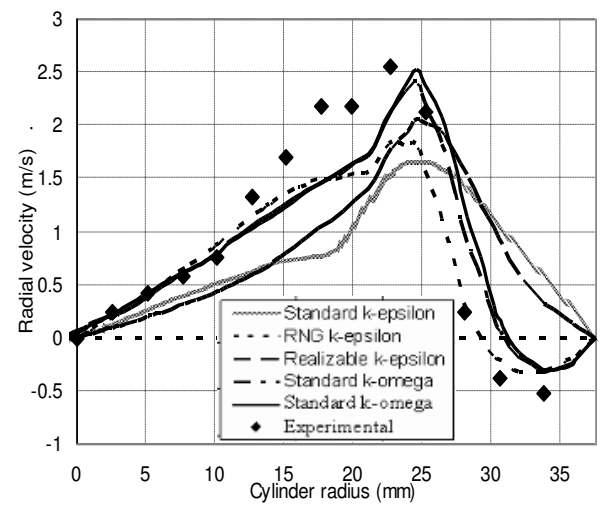

Fig.4 Radial velocity profiles at line A-A

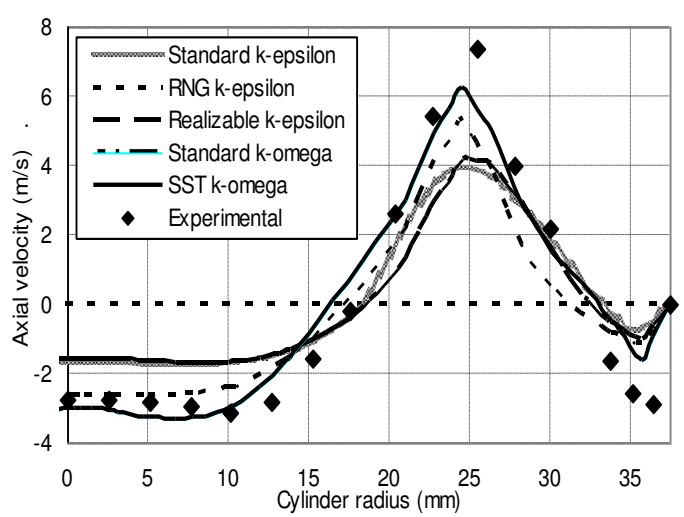

Fig.3 Axial velocity profiles at line A-A

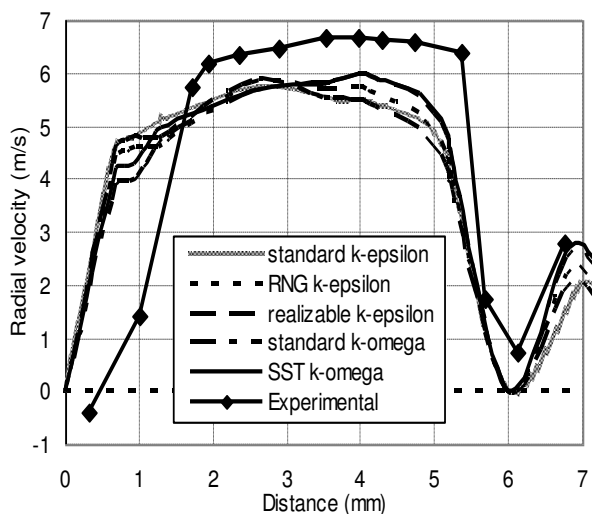

Fig.5 Radial velocity profiles at line B-B

\subsection{Full Load}

Figures 6 to 15 illustrate the previous parameters variations with both auxiliary valve opening durations and opening angle variations. The auxiliary valve opening durations are listed on the top of each figure. 


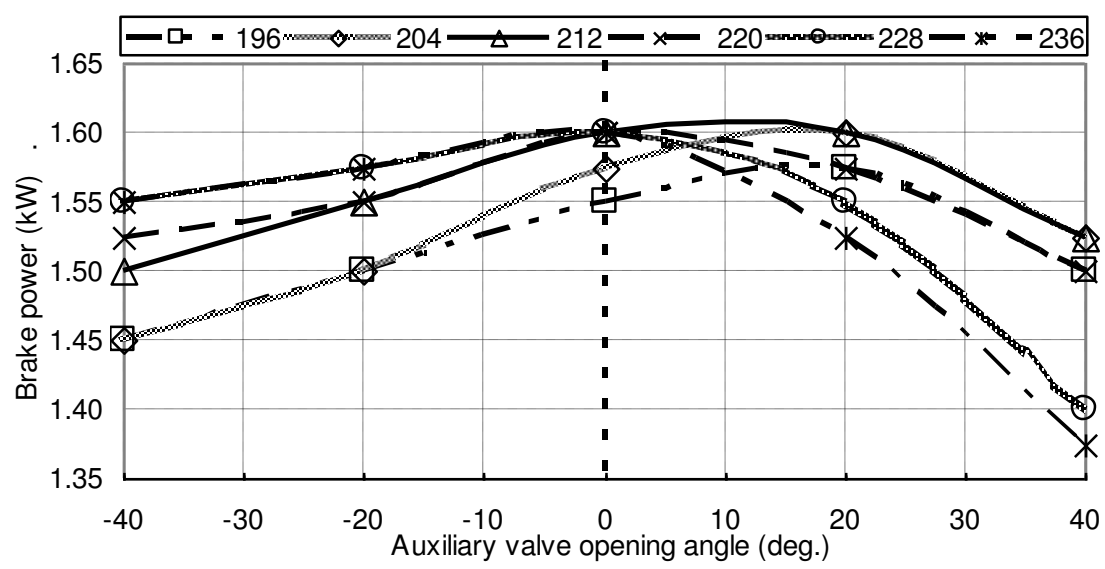

Fig. 6 Experimental variation of brake power with both auxiliary valve duration and opening angle variations

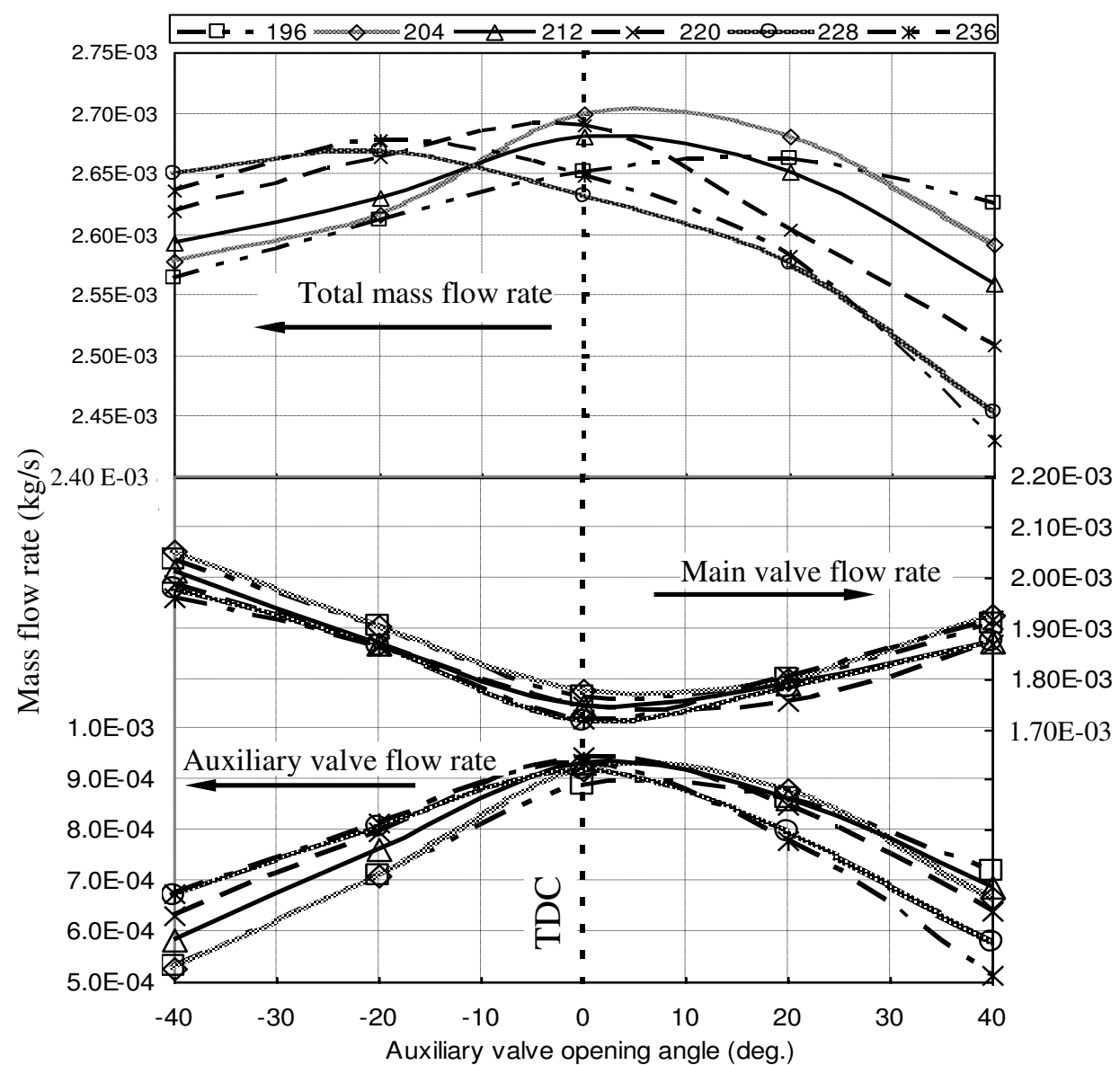

Fig. 7 Experimental variations of mass flow rates of air through intake valves with both auxiliary valve duration and opening angle variations 


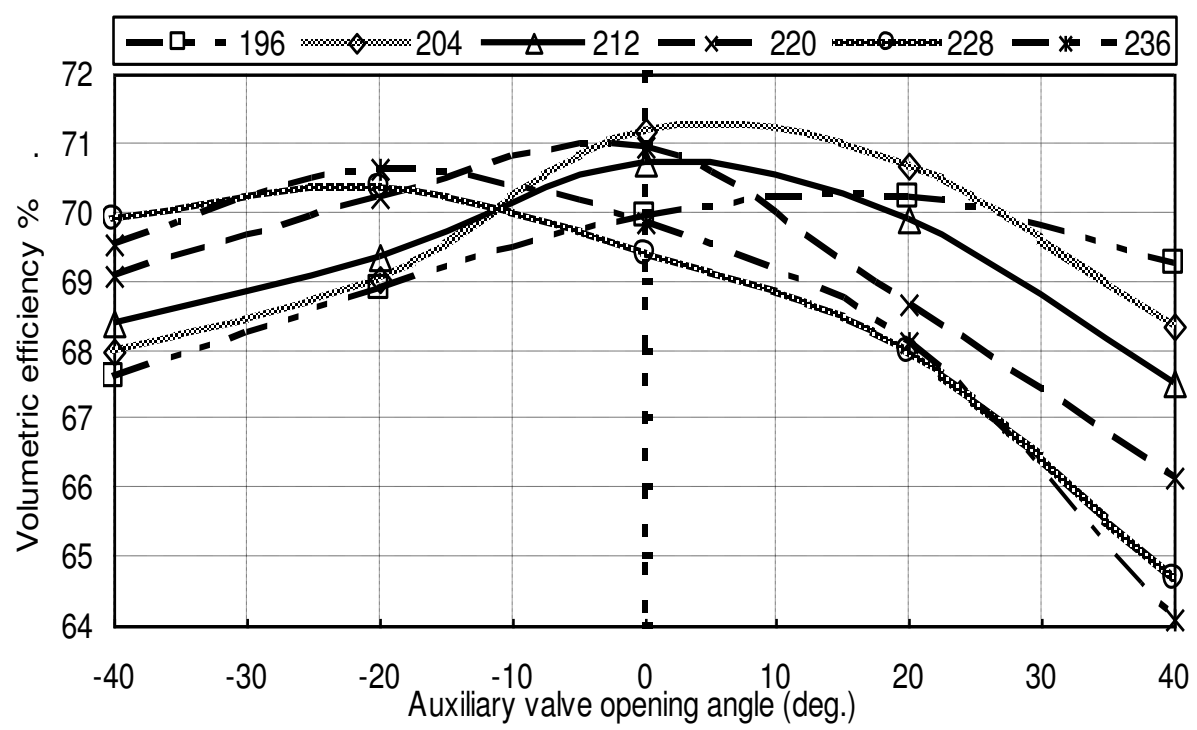

Fig. 8 Experimental variation of volumetric efficiency with both auxiliary valve duration and opening angle variations

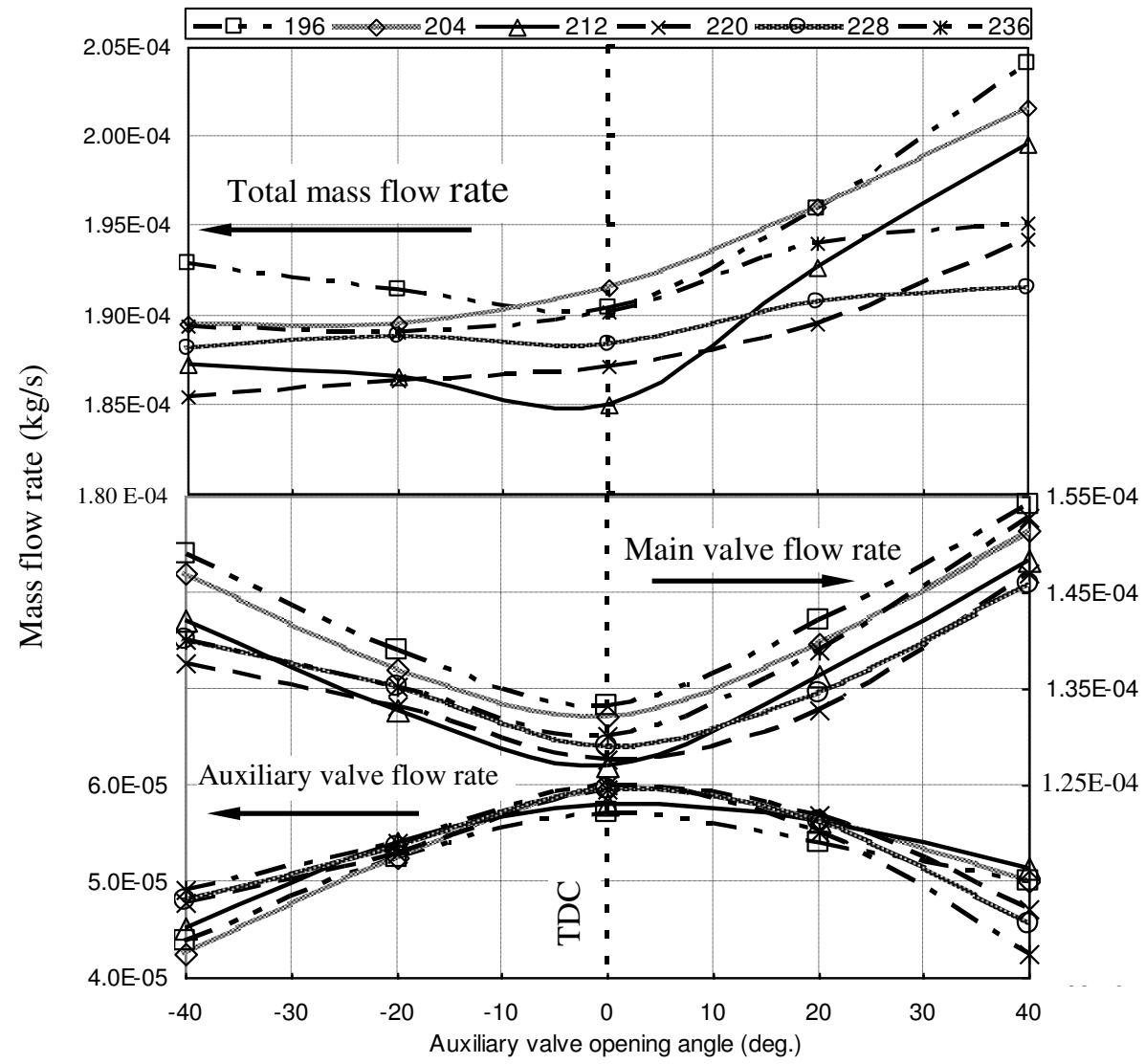

Fig. 9 Experimental variations of mass flow rates of fuel through intake valves with both auxiliary valve duration and opening angle variations 


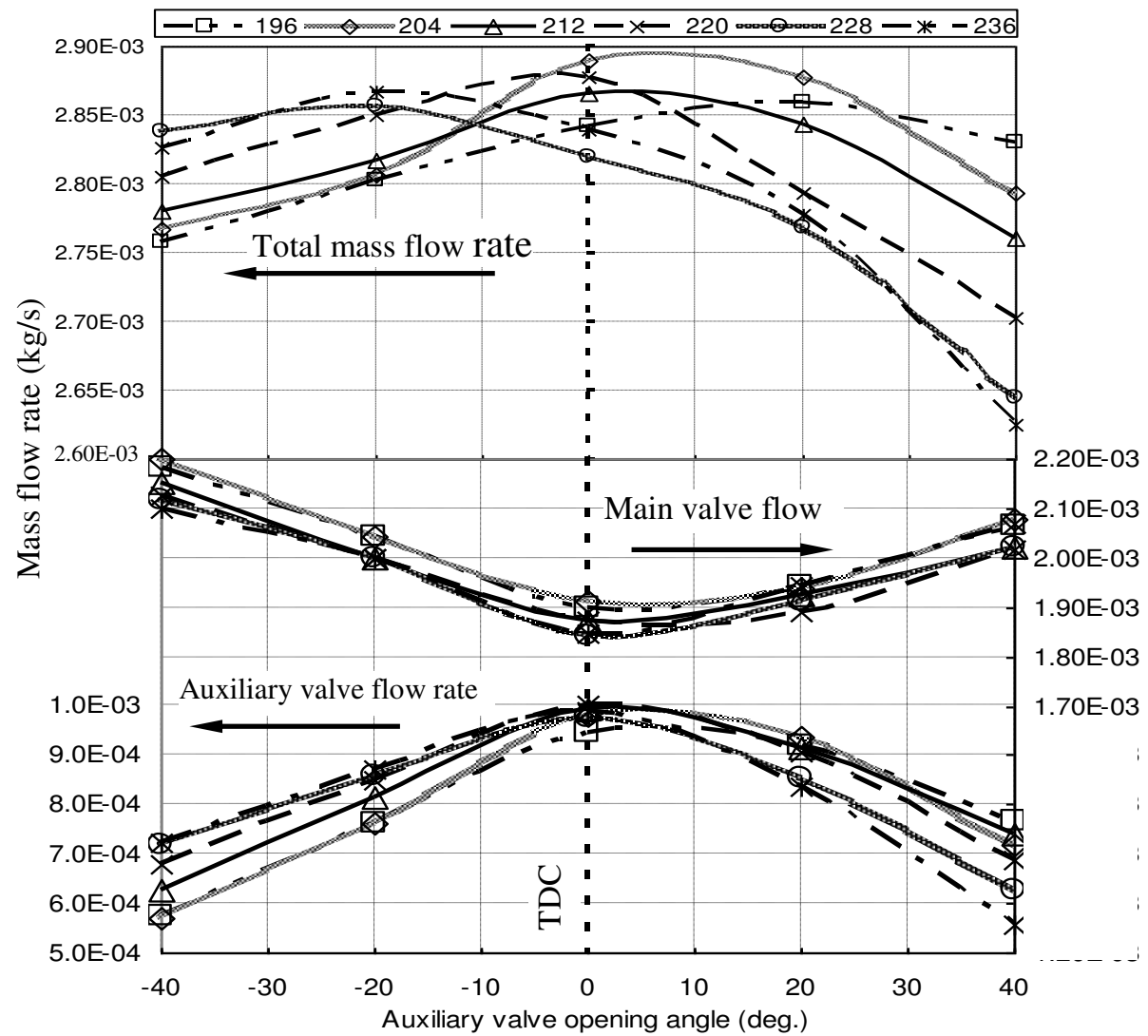

Fig.10 Experimental variations of masses flow rates of fresh charge through intake valves with both auxiliary valve duration and opening angle variations

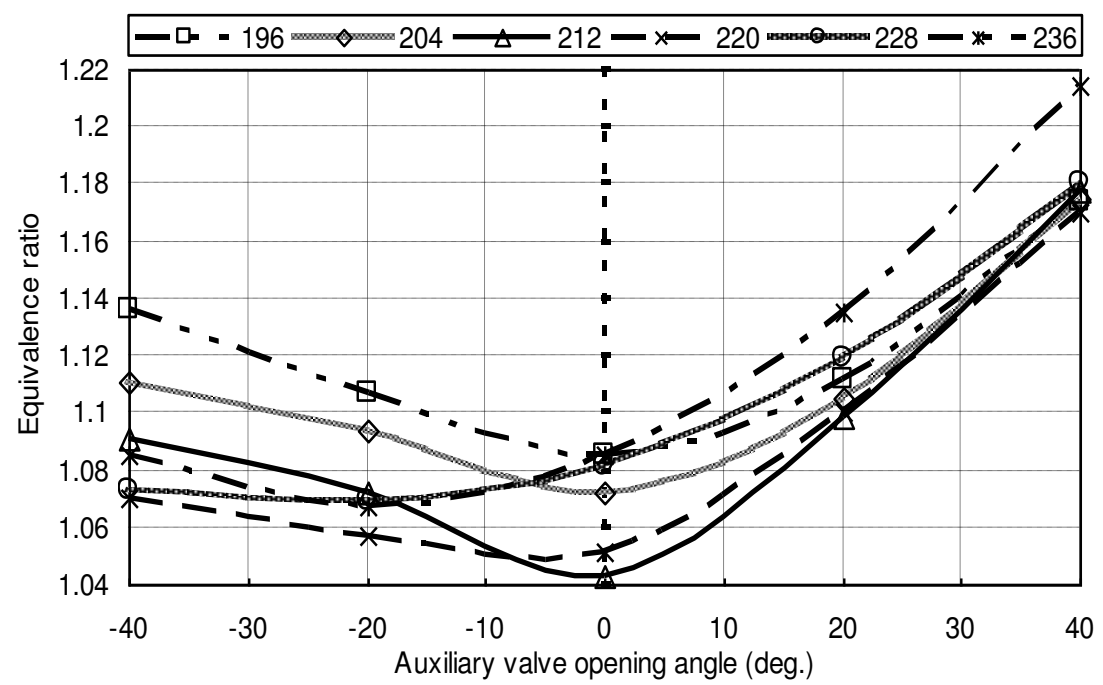

Fig. 11 Experimental variation of average equivalence ratio with both auxiliary valve duration and opening angle variations 


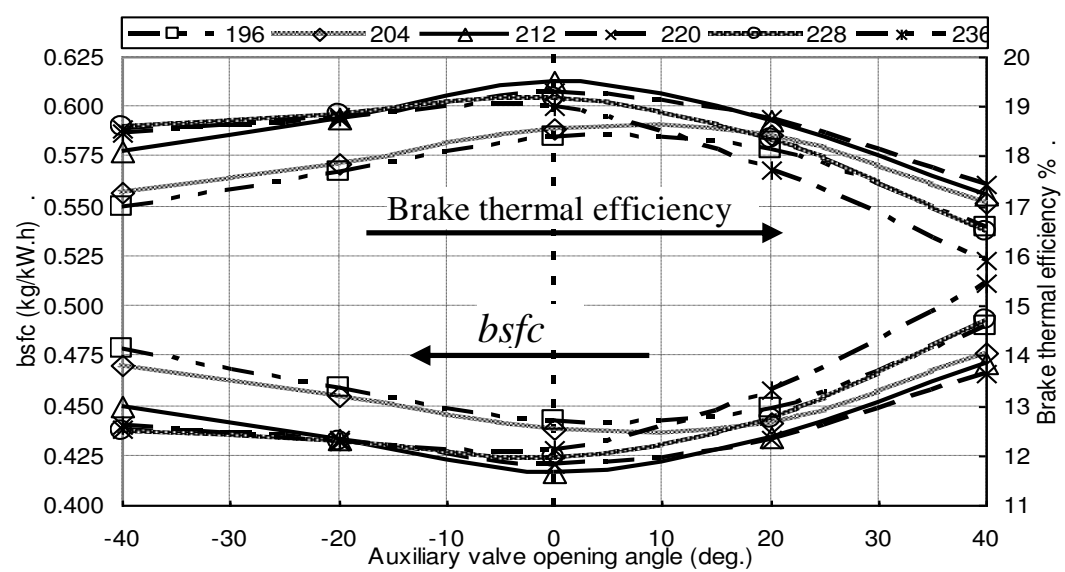

Fig. 12 Experimental variations of brake thermal efficiency and $b s f c$ with both auxiliary valve duration and opening angle variations

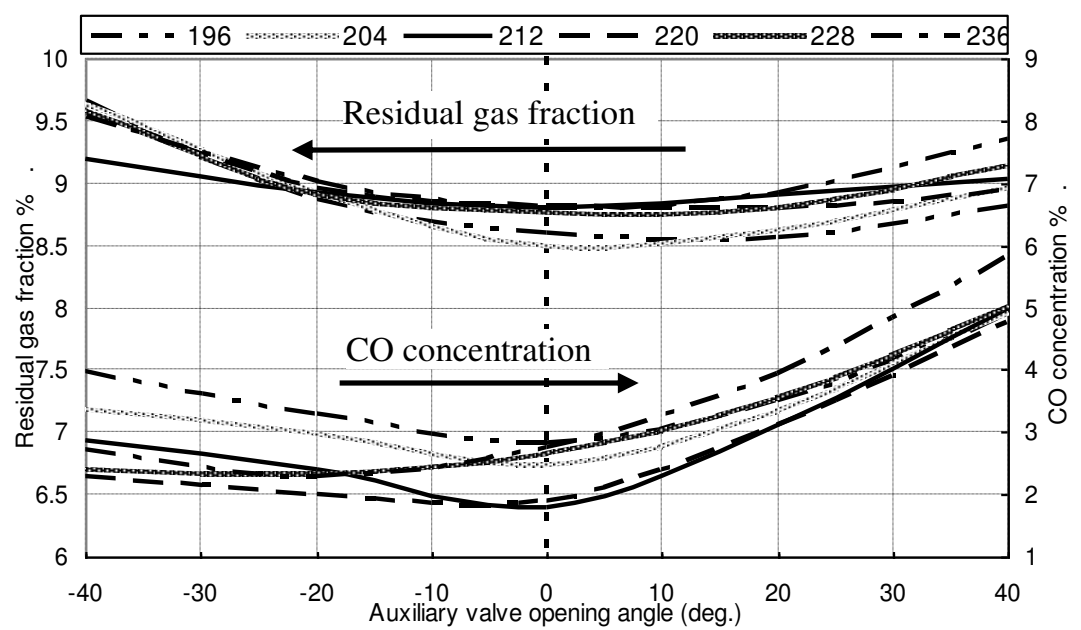

Fig.13 Calculated variations of residual gas fraction and $\mathrm{CO}$ concentration with both auxiliary valve duration and opening angle variations

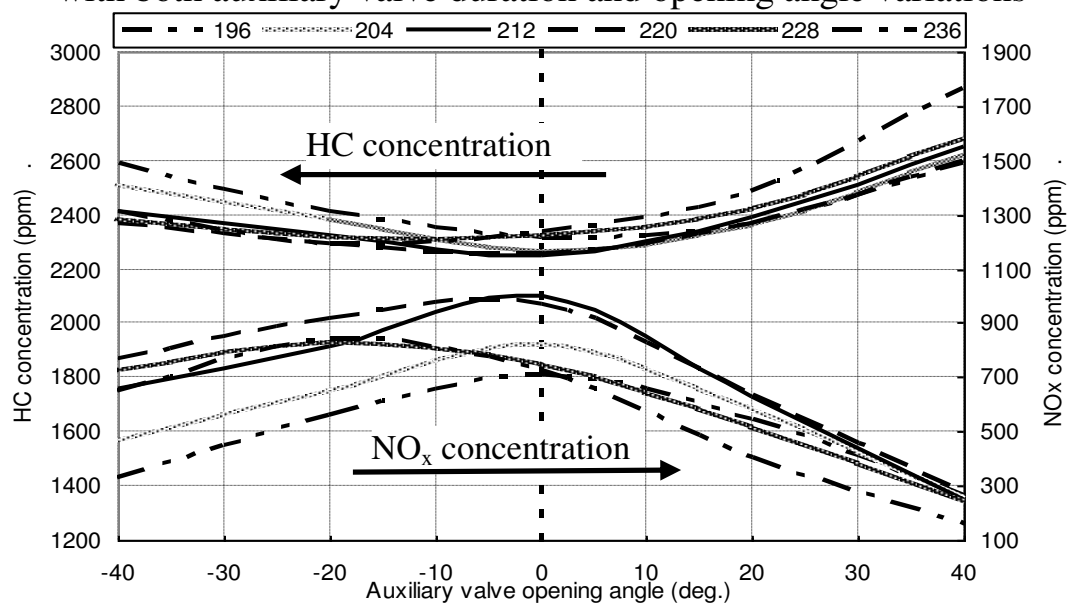

Fig. 14 Calculated variations of $\mathrm{HC}$ and $\mathrm{NO}_{\mathrm{x}}$ concentrations with both auxiliary valve duration and opening angle variations 


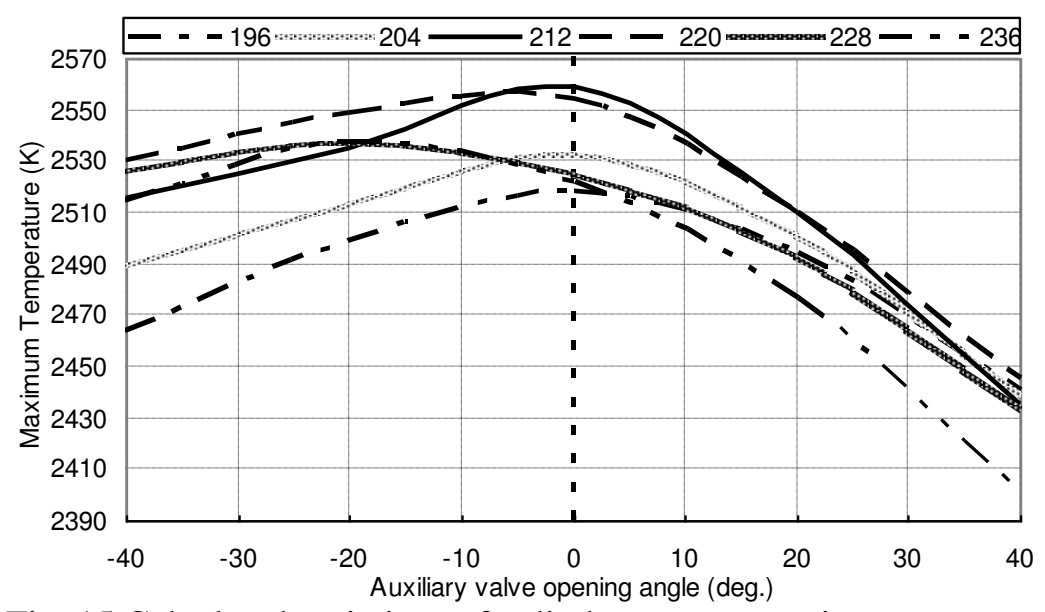

Fig. 15 Calculated variations of cylinder content maximum temperature with both auxiliary valve duration and opening angle variations

From Fig. 6 it is obvious that the maximum brake power increases from 1.45 $\mathrm{kW}$ for the original engine to $1.62 \mathrm{~kW}$ for the VVT engine at auxiliary valve opening duration of $212^{\circ}$ and opening angle of $12^{\circ}$ CA ATDC with a variation percentage of $11.7 \%$.

Shifting the valve opening angle from $-40^{\circ}$ to 0.0 in Fig. 7 increases mass flow rate of air through the auxiliary valve and decreases it through the main valve for all valve durations but the total mass flow rate increases except for duration of $228^{\circ}$. This is due to the reverse flow of exhaust gases through the auxiliary valve at early opening and its reduction when shifting the opening angle toward TDC. From $7^{\circ}$ to $40^{\circ}$, mass flow rate of air decreases through the auxiliary valve and increases through the main valve and the total mass flow rate decreases. This is due to late closing angle of the auxiliary valve which causes reverse flow through it at the end of intake process. Volumetric efficiency in Fig. 8 has the same trend of the total mass flow rate in Fig. 7. The masses flow rates of fuel through both auxiliary and main intake valves in Fig. 9 have the same trend of masses flow rates of air through the same valves in Fig.7. The total mass flow rate of fuel in Fig. 9 is approximately constant from $-40^{\circ}$ to $0.0^{\circ}$ for each duration where the decrease in mass flow rate of fuel through the main valve is approximately equal to its increase through the auxiliary valve. Small increase in total mass flow rate of fuel occurred from $0.0^{\circ}$ to $40^{\circ}$ as the increase of mass flow rate fuel through main valve is larger than the decrease through the auxiliary valve in this range. Masses flow rates of fresh charge through the intake valves in Fig. 10 take approximately the same trend of masses flow rate of air in Fig. $\mathbf{7}$ as the mass flow rate of fuel is relatively small compared with that of air.

Figure 11 shows the equivalence ratio inside the cylinder where it decreases in the range from $-40^{\circ}$ to $0^{\circ}$ as the total mass flow rate of air increases while the total mass flow rate of fuel is approximately constant in this range. It increases in the rest range due to the decrease of the total mass flow rate of air and the increase of the total mass flow rate of fuel in this range. 
Brake thermal efficiency increases by shifting the opening angle toward TDC due to fresh charge increase which means higher pressure at the end of compression and combustion and hence higher net work. It decreases after TDC due to fresh charge decrease. Maximum brake thermal efficiency occurs at 212 valve duration and TDC opening with a value of $19.5 \%$ and variation percentage $\mathrm{V}_{1}=16.89 \%$ as shown in Fig. 12 as this condition has the minimum value of fuel consumption and approximately maximum value of brake power as shown in Fig. 6. The corresponding value of $b s f c=$ $0.4163 \mathrm{~kg} /(\mathrm{kW} . \mathrm{h})$ with variation percentage $\mathrm{V}_{1}=-14.34 \%$. At this condition $34.8 \%$ of the total mass of air and $31.4 \%$ of the total mass of fuel enters through the auxiliary valve while the rest enters through the main valve.

$\mathrm{CO}$ is a result of incomplete combustion which increases with the increase of equivalence ratio and hence $\mathrm{CO}$ concentration in Fig. 13 follows the trend of equivalence ratio in Fig. 11.

Residual gas fraction decreases in the range from $-40^{\circ}$ to $5^{\circ}$ in Fig. $\mathbf{1 3}$ due to the decrease of exhaust flow through the auxiliary valve which occurs at early opening angles. Then increases in the rest range due to the decrease of fresh charge as shown in Fig. 10.

$\mathrm{NO}_{\mathrm{x}}$ formation is an endothermal reaction depending on cylinder content temperature which increases with the increase of equivalence ratio till stoichiometric condition and then decreases at rich mixtures due to dissociation. Hence, $\mathrm{NO}_{\mathrm{x}}$ concentration trend in Fig. 14 follows the excess air factor which is the inverse of the equivalence ratio trend in Fig. 11.

$\mathrm{HC}$ concentration depends on the wall quench distance, craves volumes and oxidation rate. From the simulation model, it is found that, change in wall quench distance is small as the variation in flame speed is small in the range of equivalence ratio that is achieved in these experiments and craves hydrocarbons variation is also small relative to the total amount of hydrocarbons. The important parameter is the oxidation rate which increases with the cylinder content temperature increase. Then HC in Fig. 14 has approximately a trend opposite to the cylinder content maximum temperature in Fig. 15.

Maximum and minimum values of the parameters under consideration and their values at maximum brake thermal efficiency are illustrated in table 2. Although minimum values of $\mathrm{NO}_{\mathrm{x}}$ are required, the maximum values are recorded in the table as the maximum value occurred near the maximum brake thermal efficiency.

From Figs. 6 to 15 and table 2 we can reach the following results, Valve duration of $212^{\circ} \mathrm{CA}$ and TDC opening angle is the best condition for running engine at full load as it causes maximum brake thermal efficiency, approximately maximum brake power and mass flow rate of fresh charge. It also causes approximately minimum residual gas fraction, $\mathrm{CO}$ concentration and $\mathrm{HC}$ concentration, in spite of achieving nearly maximum $\mathrm{NO}_{\mathrm{x}}$ concentration.

\subsection{Part Loads}

The same experiments and simulation calculation are carried out at $1.1 \mathrm{~kW}, \quad 0.75 \mathrm{~kW}$ and $0.4 \mathrm{~kW}$. It is found that: (1) $212^{\circ} \mathrm{CA}$ valve duration and $2.5^{\circ}$ opening angle is the best condition at $1.1 \mathrm{~kW}$. (2) $220^{\circ} \mathrm{CA}$ valve duration and TDC opening angle is the best condition at $0.75 \mathrm{~kW}$. (3) $228^{\circ} \mathrm{CA}$ valve duration and TDC opening angle is the 
best condition at $0.4 \mathrm{~kW}$. These conditions cause maximum brake thermal efficiencies, approximately maximum volumetric efficiencies, approximately minimum residual gas fraction and $\mathrm{HC}$ emissions but they increase $\mathrm{NO}_{\mathrm{x}}$ emissions at loads with rich mixture. Figures 16 to 21 show variations of the different parameters for both original engine and VVT engine at $\xi_{\eta_{b h \max }}$ at different loads. Table $\mathbf{3}$ shows magnitudes of the same parameters and variations percentages compared with the original engine.

Table 2 Magnitudes and variations of engine parameters

\begin{tabular}{|c|c|c|c|c|c|c|}
\hline \multirow[t]{2}{*}{ Engine parameter } & \multirow[t]{2}{*}{ description } & \multirow[t]{2}{*}{ magnitude } & \multicolumn{2}{|c|}{ Auxiliary valve } & \multirow{2}{*}{$\begin{array}{l}\text { Variation } \\
\mathrm{V}_{1} \%\end{array}$} & \multirow{2}{*}{$\begin{array}{c}\text { Variation } \\
\mathrm{V}_{2} \%\end{array}$} \\
\hline & & & duration & $\begin{array}{c}\text { opening } \\
\text { angle }\end{array}$ & & \\
\hline \multirow[t]{2}{*}{ Brake power $(\mathrm{kW})$} & Maximum & 1.61 & 212 & 12 & 10.9 & \multirow{2}{*}{-0.92} \\
\hline & At $\eta_{b \text { th } \max }$ & 1.6 & 212,220 & 0 & 10.34 & \\
\hline \multirow{2}{*}{$\begin{array}{l}\text { Mass flow rate of air } \\
(\mathrm{kg} / \mathrm{s})\end{array}$} & Maximum & $2.705 \mathrm{E}-3$ & 204 & 7 & 8.6 & \multirow{2}{*}{-0.185} \\
\hline & At $\eta_{b t h \max }$ & $2.68 \mathrm{E}-3$ & 212 & 0 & 7.67 & \\
\hline \multirow{2}{*}{$\begin{array}{l}\text { Mass flow rate of } \\
\text { fuel }(\mathrm{kg} / \mathrm{s})\end{array}$} & Minimum & $1.848 \mathrm{E}-4$ & 212 & -2.5 & -5.75 & \multirow{2}{*}{0.54} \\
\hline & At $\eta_{b t h \max }$ & $1.85 \mathrm{E}-4$ & 212 & 0 & -5.6 & \\
\hline \multirow{2}{*}{$\begin{array}{l}\text { Mass flow rate of } \\
\text { fresh charge }(\mathrm{kg} / \mathrm{s})\end{array}$} & Maximum & $2.895 \mathrm{E}-3$ & 204 & 6 & 7.8 & \multirow{2}{*}{1.0} \\
\hline & At $\eta_{b t h \max }$ & $2.866 \mathrm{E}-3$ & 212 & 0 & 6.7 & \\
\hline \multirow[t]{2}{*}{ Equivalence ratio } & Minimum & 1.043 & 212 & 0 & -12.35 & \multirow{2}{*}{0.0} \\
\hline & At $\eta_{b t h \max }$ & 1.043 & 212 & 0 & -12.35 & \\
\hline \multirow{2}{*}{$\begin{array}{l}\text { Volumetric } \\
\text { efficiency \% }\end{array}$} & Maximum & 71.25 & 204 & 7 & +11 & \multirow{2}{*}{-0.76} \\
\hline & At $\eta_{b t h \max }$ & 70.71 & 212 & 0 & 10.14 & \\
\hline \multirow{2}{*}{$\begin{array}{l}\text { Residual gas fraction } \\
\%\end{array}$} & Minimum & 8.48 & 204 & 4 & -11.83 & \multirow[b]{2}{*}{0.2} \\
\hline & At $\eta_{b t h \max }$ & 8.8 & 212 & 0 & -8.58 & \\
\hline \multirow[t]{2}{*}{$\mathrm{CO}$ concentration $\%$} & Minimum & 1.75 & 212 & -2 & -63.8 & \multirow{2}{*}{3.78} \\
\hline & At $\eta_{b t h \max }$ & 1.78 & 212 & 0 & -63.5 & \\
\hline \multirow{2}{*}{$\begin{array}{c}\mathrm{NO}_{\mathrm{x}} \text { Concentration } \\
(\mathrm{ppm})\end{array}$} & Maximum & 1007 & 212 & -2 & 368 & \multirow{2}{*}{-0.437} \\
\hline & At $\eta_{b \text { th } \max }$ & 1002.6 & 212 & 0 & 384.2 & \\
\hline \multirow{2}{*}{$\begin{array}{l}\text { HC concentration } \\
(\mathrm{ppm})\end{array}$} & Minimum & 2247 & 212 & -2 & -14.6 & \multirow{2}{*}{0.044} \\
\hline & At $\eta_{b h_{\max }}$ & 2249 & 212 & 0 & -14.54 & \\
\hline
\end{tabular}

\subsection{Performance Conclusions}

From Figs 16 to 21 and table 3 we can conclude the following results:

1- The maximum increase in brake thermal efficiency occurs at full load with a value of $16.89 \%$ and it decreases with the decrease of the load to a value of $5.3 \%$ at $0.4 \mathrm{~kW}$.

2- Variation percentages of mass flow arte of air, volumetric efficiency and fresh charge increase with the decrease of the load which means that the VVT with auxiliary intake valve improves the engine charging especially at part load. 


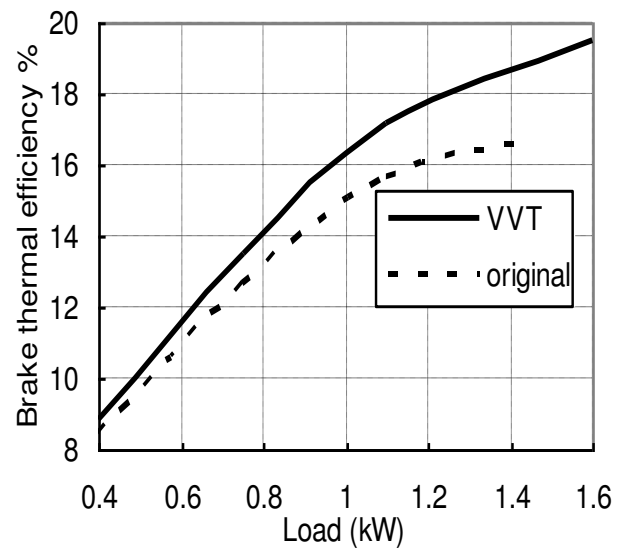

Fig.16 Variations of brake thermal efficiencies with load for original and VVT engines

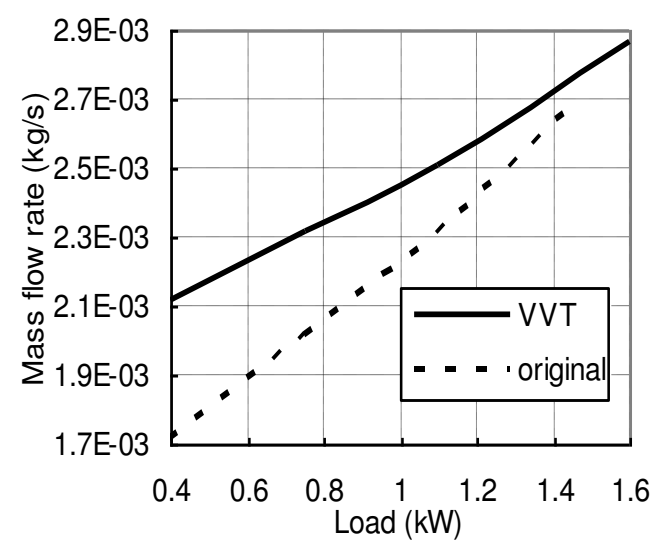

Fig.18 Variations of masses flow rate of fresh charge with load for original and VVT engines

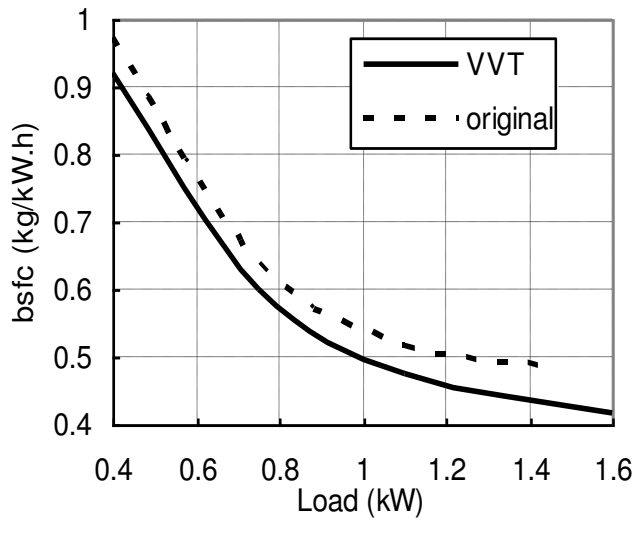

Fig.17 Variations of bsfe with load for original and VVT engines

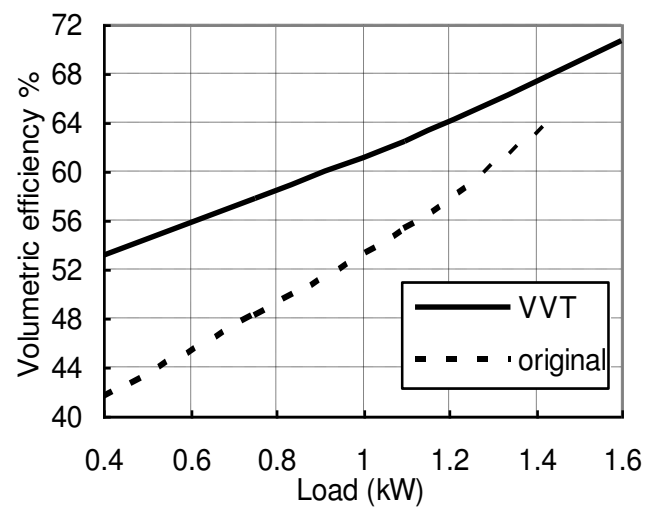

Fig.19 Variations of volumetric efficiencies with load for original and VVT engines

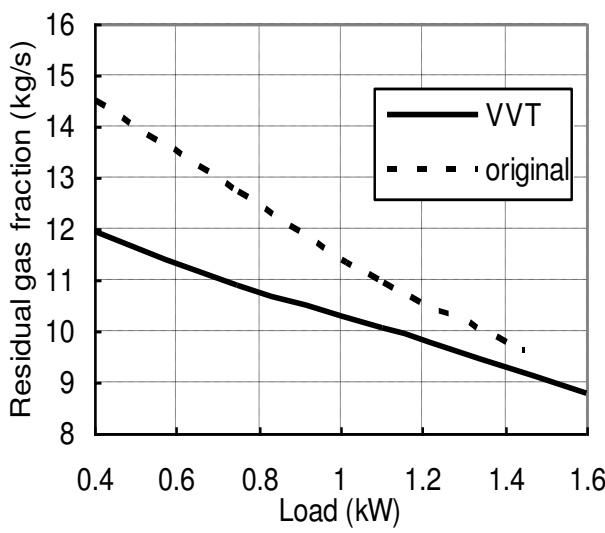

Fig.20 Variations of residual gas fractions with load for original and VVT engines

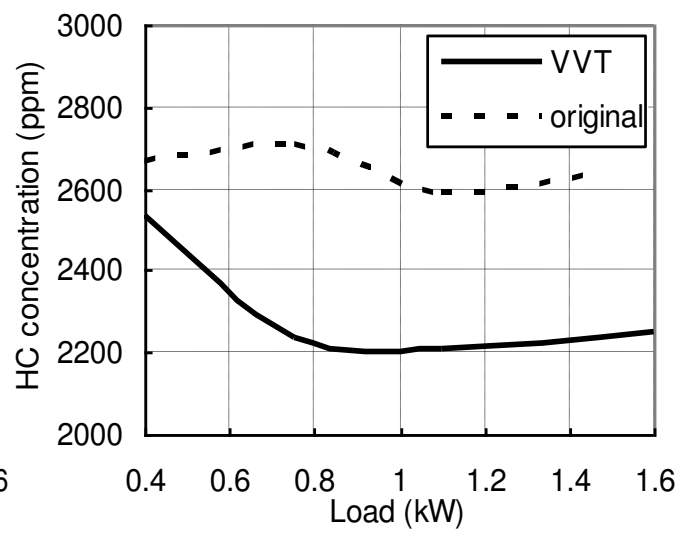

Fig.21 Variations of HC concentrations with load for original and VVT engines 
Table 3 Engine parameters at the recommended valve timing

\begin{tabular}{|c|c|c|c|c|c|}
\hline & & Full load & $1.1 \mathrm{~kW}$ & $0.75 \mathrm{~kW}$ & $0.4 \mathrm{~kW}$ \\
\hline Auxiliary valve & duration & 212 & 212 & 220 & 228 \\
\hline & opening angle & 0 & 2.5 & 0 & 0 \\
\hline Brake thermal & Magnitude & 19.5 & 17.18 & 13.51 & 8.824 \\
\hline efficiency & Variation $V_{l} \%$ & 16.89 & 9.43 & 6.38 & 5.3 \\
\hline$b s f c$ & Magnitude & 0.4163 & 0.4731 & 0.6017 & 0.921 \\
\hline & Variation $V_{l} \%$ & -14.34 & -8.68 & -5.69 & -5.05 \\
\hline Mass flow & Total & $2.681 \mathrm{E}-3$ & $2.367 \mathrm{E}-3$ & $2.188 \mathrm{E}-3$ & $2.011 \mathrm{E}-3$ \\
\hline rate of air $(\mathrm{kg} / \mathrm{s})$ & Variation $V_{l} \%$ & 7.67 & 10.1 & 16.37 & 24.91 \\
\hline & Through auxiliary \% & 34.8 & 41.9 & 44.8 & 46.3 \\
\hline Mass flow & Total & $1.85 \mathrm{E}-4$ & $1.447 \mathrm{E}-4$ & $1.254 \mathrm{E}-4$ & $1.023 \mathrm{E}-4$ \\
\hline rate of & Variation $V_{l} \%$ & -5.6 & -8.5 & -5.71 & -5.28 \\
\hline & Through auxiliary \% & 31.4 & 39.1 & 41.8 & 44.0 \\
\hline Mass flow Rate & Total & $2.866 \mathrm{E}-3$ & $2.512 \mathrm{E}-3$ & $2.313 \mathrm{E}-3$ & $2.113 \mathrm{E}-3$ \\
\hline of fresh charge & Variation $V_{l} \%$ & 6.7 & 8.84 & 14.92 & 23.01 \\
\hline$(\mathrm{kg} / \mathrm{s})$ & Through auxiliary \% & 34.6 & 41.8 & 44.6 & 46.17 \\
\hline Volumetric & Magnitude & 70.71 & 62.43 & 57.69 & 53.03 \\
\hline & Variation $V_{l} \%$ & 10.14 & 12.67 & 19.44 & 27.78 \\
\hline Residual gas & Magnitude & 8.8 & 10.05 & 10.88 & 11.94 \\
\hline fraction \% & Variation $V_{l} \%$ & -8.58 & -7.95 & -13.53 & -18.97 \\
\hline $\mathrm{NO}_{\mathrm{x}}(\mathrm{ppm})$ & Magnitude & 1002.6 & 1870 & 613 & 181.25 \\
\hline & Variation $V_{l} \%$ & 384.2 & 305 & -5.12 & -85.6 \\
\hline HC (ppm) & Magnitude & 2249 & 2208 & 2236 & 2538 \\
\hline & Variation $V_{l} \%$ & -14.5 & -14.8 & -18.66 & -3.3 \\
\hline
\end{tabular}

3- Percentages of mass flow rate of air and fuel through the auxiliary valve increase with the decrease of the load which means that the auxiliary valve effect increases at part loads.

4- Reduction of residual gas fraction increases with the decrease of the load which improves the engine performance at part loads.

5- $\mathrm{NO}_{\mathrm{x}}$ increases approximately four times at full load and three times at $1.1 \mathrm{~kW}$ where the equivalence ratio is greater than stoichiometric which is considered as a disadvantage of using VVT with auxiliary valve at loads with rich mixtures. Its Variation percentage is negative at $0.75 \mathrm{~kW}$ and $0.4 \mathrm{~kW}$ which means improvement of $\mathrm{NO}_{\mathrm{x}}$ concentration at part loads with lean mixtures.

6- Variation percentage of $\mathrm{HC}$ concentration is negative for the whole range of load which means reduction in $\mathrm{HC}$ emissions over the whole range of load.

\section{THREE DIMENSIONAL ANALYSIS}

The engine used in this study was essentially designed for knock testing and hence the designers did not care of designing the inlet port, cylinder head surface and piston 
surface to produce good swirl and tumble inside the cylinder where all ducts are of direct type and both cylinder head and piston surfaces are flat. Simulation analysis is carried out for both original and VVT engines at the same previous loads with $196^{\circ} \mathrm{CA}$ auxiliary valve duration using Fluent 6.3.26 code. The engine parameters under consideration are:

1. Swirl is assumed positive for clockwise (CW) rotation [16]. Swirl ratio is calculated according to the following equation:

$$
\text { Swirl ratio }=\frac{1}{\omega_{e}} \sum_{i=1}^{n} d M_{\text {angular }} / \sum_{i=1}^{n} d M_{\text {inienia }}
$$

Where $\mathrm{dM}_{\text {angular }}$ is the angular momentum of the mass in cell $\boldsymbol{i}$ around the cylinder axis, $\mathrm{dM}_{\text {inertia }}$ is the mass moment of inertia of the same cell around the same axis, $\boldsymbol{i}$ is the cell under consideration, $\boldsymbol{n}$ is the total number of cells and $\omega_{e}$ is the engine angular velocity.

2. Tumbles are assumed positive for counter clockwise (CCW) rotation [16] around two axes: (a) Axis parallel to $\mathrm{x}$ axis in the middle of the cylinder height at each crank angle called //x axis. (b) Axis parallel to $y$ axis in the middle of the cylinder height at each crank angle called //y axis. Both tumbles are calculated with equation (1) with changing the axis of calculation.

3. Equivalences ratios (through main valve, auxiliary valve, average value through the cylinder and at spark plug location at the end of induction process) are calculated to check if the engine can be used as stratified engine or not.

As fluent 6.3.26 code cannot calculate swirl, tumbles and equivalence ratio directly, some subroutines are constructed and joined to it to calculate these parameters.

Figure 22 shows velocity vectors distribution through sections 30 and $70 \mathrm{~mm}$ apart from cylinder head surface for original and VVT engines at the end of intake stroke for full load condition. Theses sections represent the middle third of the cylinder where most of the swirl occurs. It is obvious that the presence of the auxiliary valve reduces the maximum velocity from $12.5 \mathrm{~m} / \mathrm{s}$ to $8.5 \mathrm{~m} / \mathrm{s}$. It also does not improve the velocity vectors distribution around the cylinder axis and hence swirl is decayed. The decay happens for two reasons: (1) Presence of auxiliary valve reduces inlet flow velocity through both valves. (2) Velocity vectors at the auxiliary inlet valve produces swirl opposite to that of the main valve around the cylinder axis as shown in Fig 23. Figure 22 shows also axial velocity distribution at levels $20,40,60$, and $80 \mathrm{~mm}$ apart from cylinder head surface at the same conditions where the auxiliary valve reduces the maximum axial velocity from $10.25 \mathrm{~m} / \mathrm{s}$ to $7.7 \mathrm{~m} / \mathrm{s}$. It also decays the axial velocity in the left hand side in $x-z$ and $y-z$ planes and hence tumble is decayed.

Presence of the auxiliary valve decays swirl through the intake stroke at different opening angles as shown in Figs. $\mathbf{2 4}$ and $\mathbf{2 5}$ while the original engine gives maximum swirl at the end of intake stroke for all loads. 


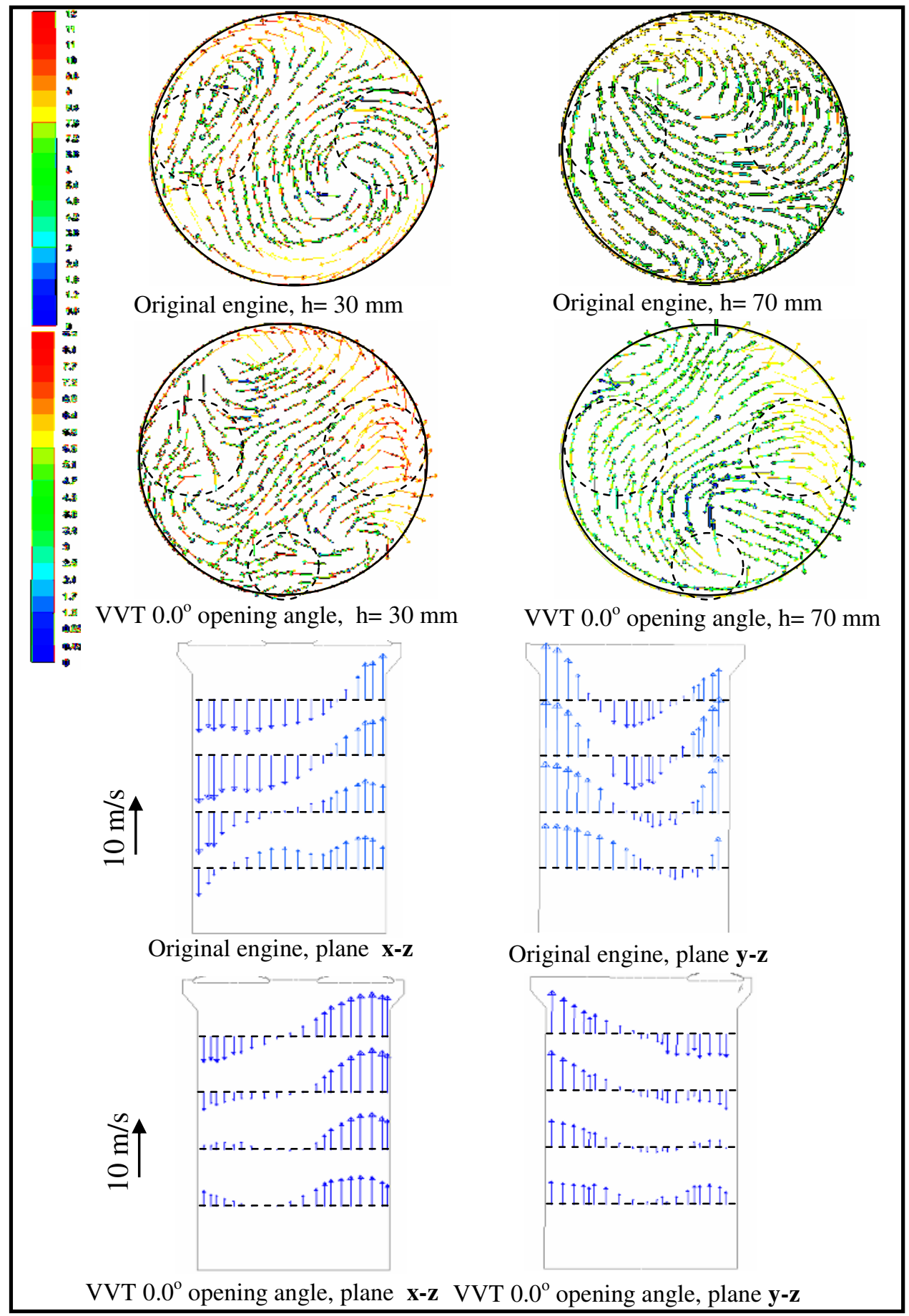

Fig. 22 Velocity vectors distribution through the selected sections for original engine and VVT engine at $0.0^{\circ}$ opening angle of the auxiliary valve 


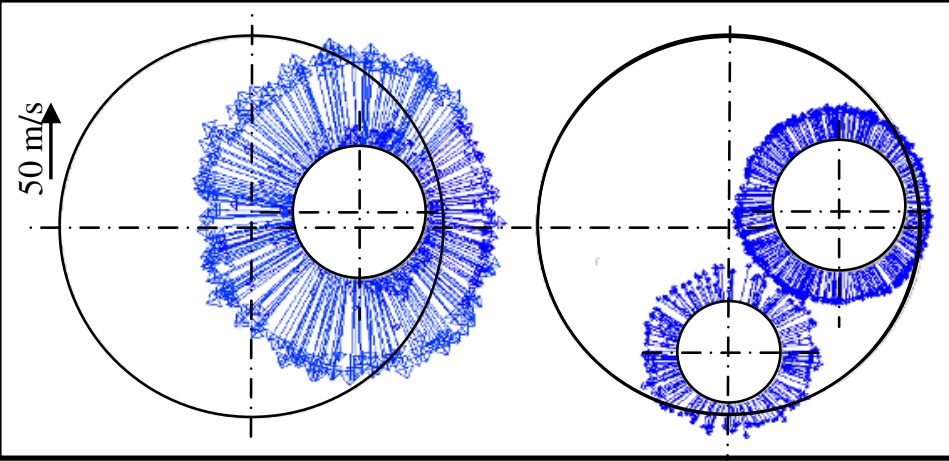

Fig. 23 Velocity vectors distribution through the intake valve curtain area for the original and VVT engines at: (a) $120^{\circ} \mathrm{CA}$ ATDC

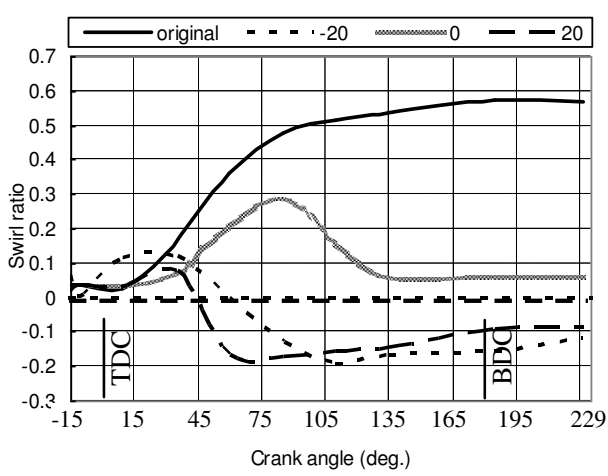

Fig. 24 Variations of swirl ratio through the intake stroke For $1.1 \mathrm{~kW}$

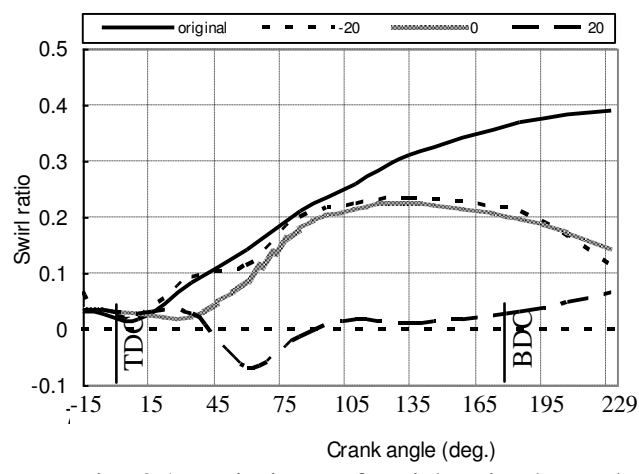

Fig. 25 Variations of swirl ratio through the intake stroke For $0.4 \mathrm{~kW}$

Figures 26 and $\mathbf{2 7}$ show tumble variation around //y axis through the intake stroke at different loads where presence of auxiliary valve reduces tumble ratio for two reasons: (1) It reduces inlet velocity through the valves. (2) It generates tumble in the opposite direction of that of the main valve.

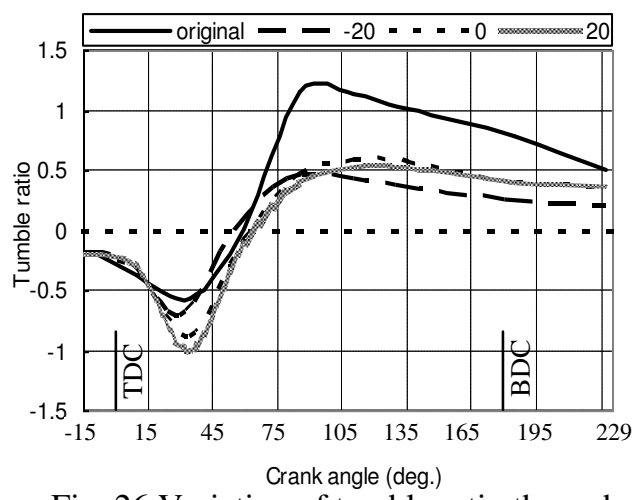

Fig. 26 Variation of tumble ratio through the intake stroke For full load

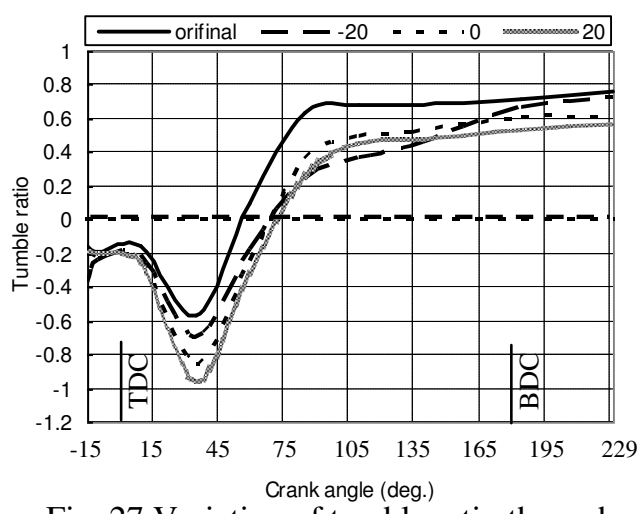

Fig. 27 Variation of tumble ratio through the intake stroke For $0.4 \mathrm{~kW}$ 
Figures 28 and 29 show tumble variation around //x axis through the intake stroke at different loads where the presence of auxiliary valve increases tumble ratio in spite of the inlet velocity reduction through the valves. This is because the valve is located symmetrically about y-z plane as shown in Fig. 1.

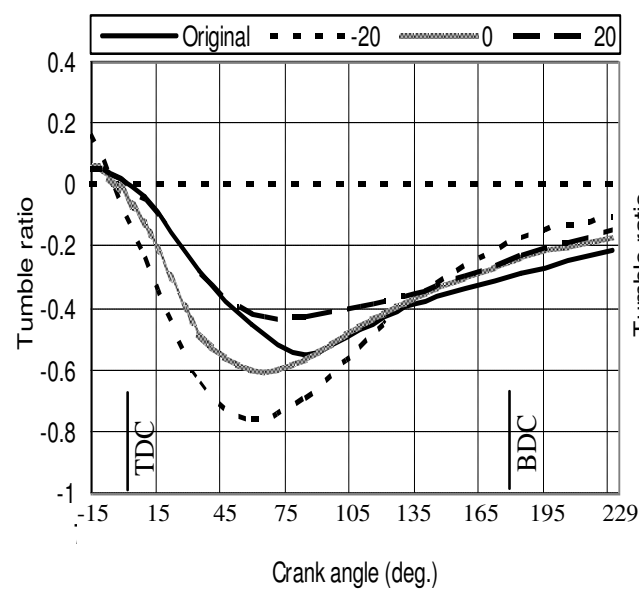

Fig. 28 Variations of tumble ratio through the intake stroke For full load

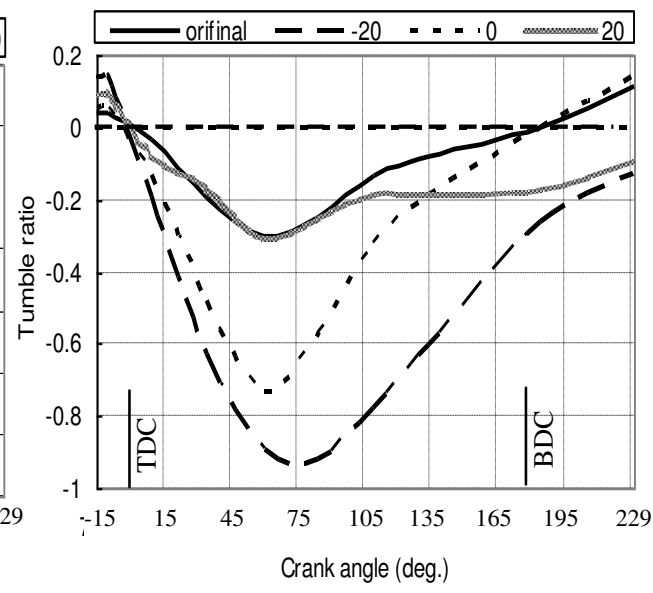

Fig. 29 Variations of tumble ratio through the intake stroke For $0.4 \mathrm{~kW}$

Figures $\mathbf{3 0}$ and $\mathbf{3 1}$ show main, auxiliary, average and at spark plug location equivalences ratios variations with the opening angle for different loads. The average equivalences ratios in the range from $0.0^{\circ}$ to $2.5^{\circ} \mathrm{CA}$ which are suggested for operation from table 3, at full load, $1.1 \mathrm{~kW}, 0.75 \mathrm{~kW}$ and $0.4 \mathrm{~kW}$, are $1.08,0.98,0.89$ and 0.81 , respectively, while the corresponding values at spark plug are 1.12, 1.03, 0.92 and 0.84 , respectively. The difference between the average and spark plug location equivalence values is very small compared with stratified engines with electronic injection. The average equivalence ratio at light loads of Mitsubishi GDI engine [17] is 0.38 while its value at spar plug location is 0.8 .

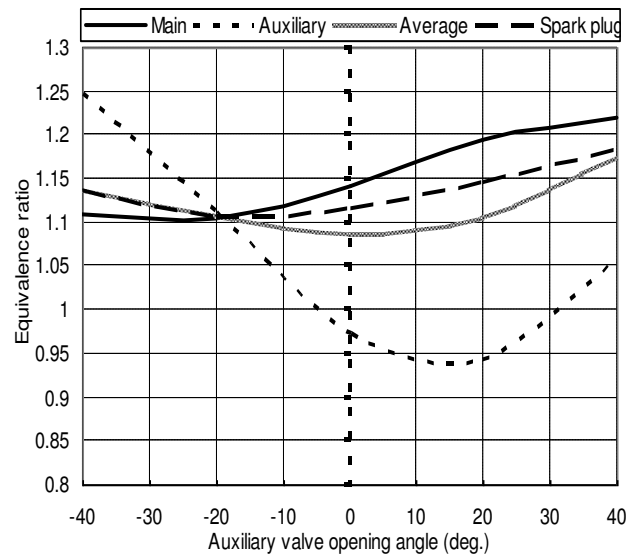

Fig. 30 Variations of equivalences ratios with auxiliary valve opening angle at full load

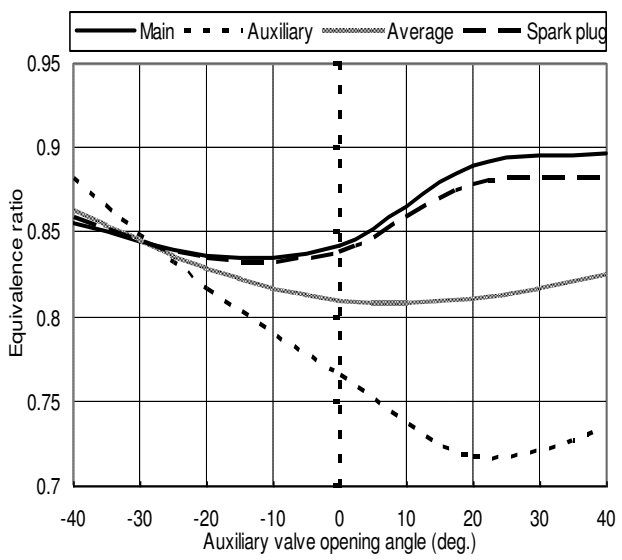

Fig. 31 Variations of Equivalences ratios with auxiliary valve opening angle at $0.4 \mathrm{~kW}$ 


\subsection{Three Dimensional Analysis Conclusions}

1. The auxiliary valve with variable timing strategy reduces swirl through the intake stroke. Helical inlet ports must be used for improving swirl. If it is not sufficient, swirl generator can be used.

2. It also reduces tumble motion. For improving tumble motion, the cylinder head surface must be pent-roof type and the two inlet valves must be fastened in one side of the roof with a suitable design of piston surface.

3. Very small stratification can be achieved by different mixtures strength through valves compared with electronic injection engines.

\section{THE VVT MECHANISM}

The VVT mechanism in [11] which designed for one cylinder engines is redesigned to suit multi-cylinder engines. The VVT mechanism depends on multi-face follower and conventional camshaft as shown in Fig. 32. The multi-face follower has twelve faces. Each face consists of two inclined surfaces with the same inclination angle $\theta$, joined together with $11 \mathrm{~mm}$ fillet radius surface. The inclination angles of the faces starts from $0^{\circ}$ to $11^{\circ}$ with step $1^{\circ}$ and hence the valve opening duration increases $4^{\circ} \mathrm{CA}$ with each step of rotation of the follower around its axis. Both cam and follower surfaces are rounded with the same radius as shown in the side view in Fig. 32 and the follower faces are joined together with $2 \mathrm{~mm}$ fillet radius surface for easy transmission between faces.

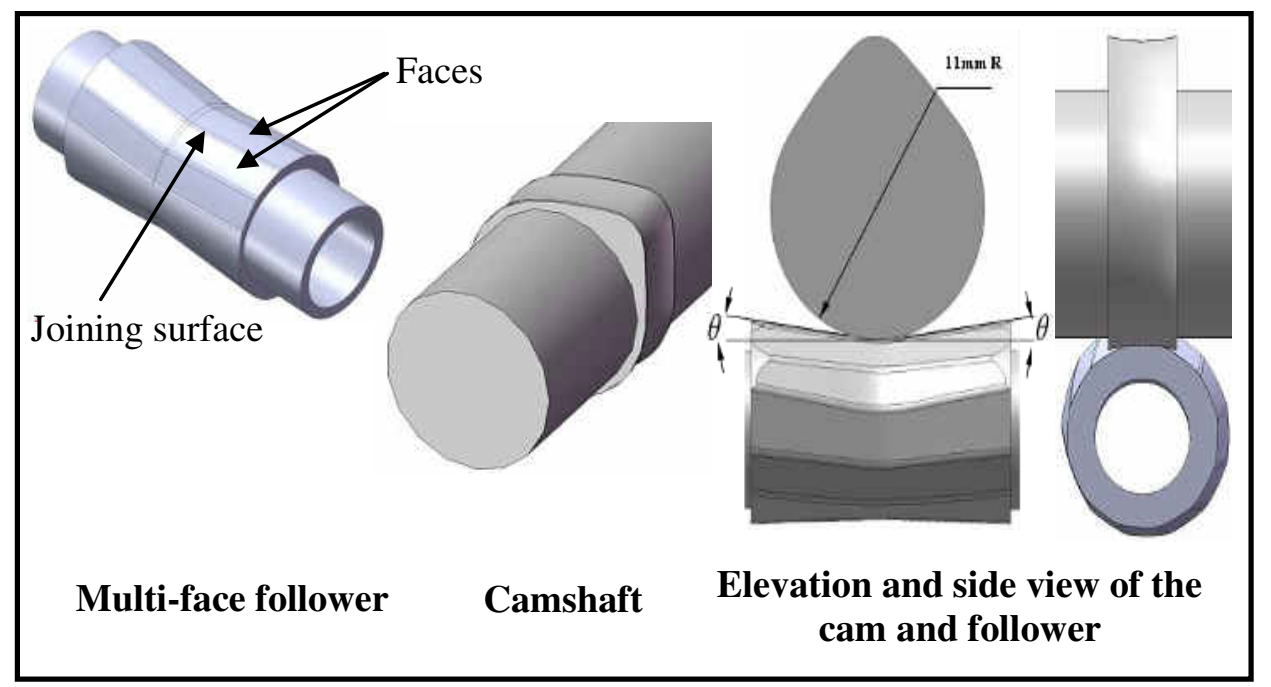

Fig. 32 Multi-face follower and cam assembly

Figure 33 shows complete assembly of the mechanism for four-cylinder engine. The camshaft is driven by sprocket gears (1), (2) and camshaft gear (3). Main intake and exhaust valves are driven by cams on the same camshaft. The multi-face follower is connected to gear (4) which is driven by rack (5) for changing its faces with the load variation and hence the auxiliary valve timing is varied. 


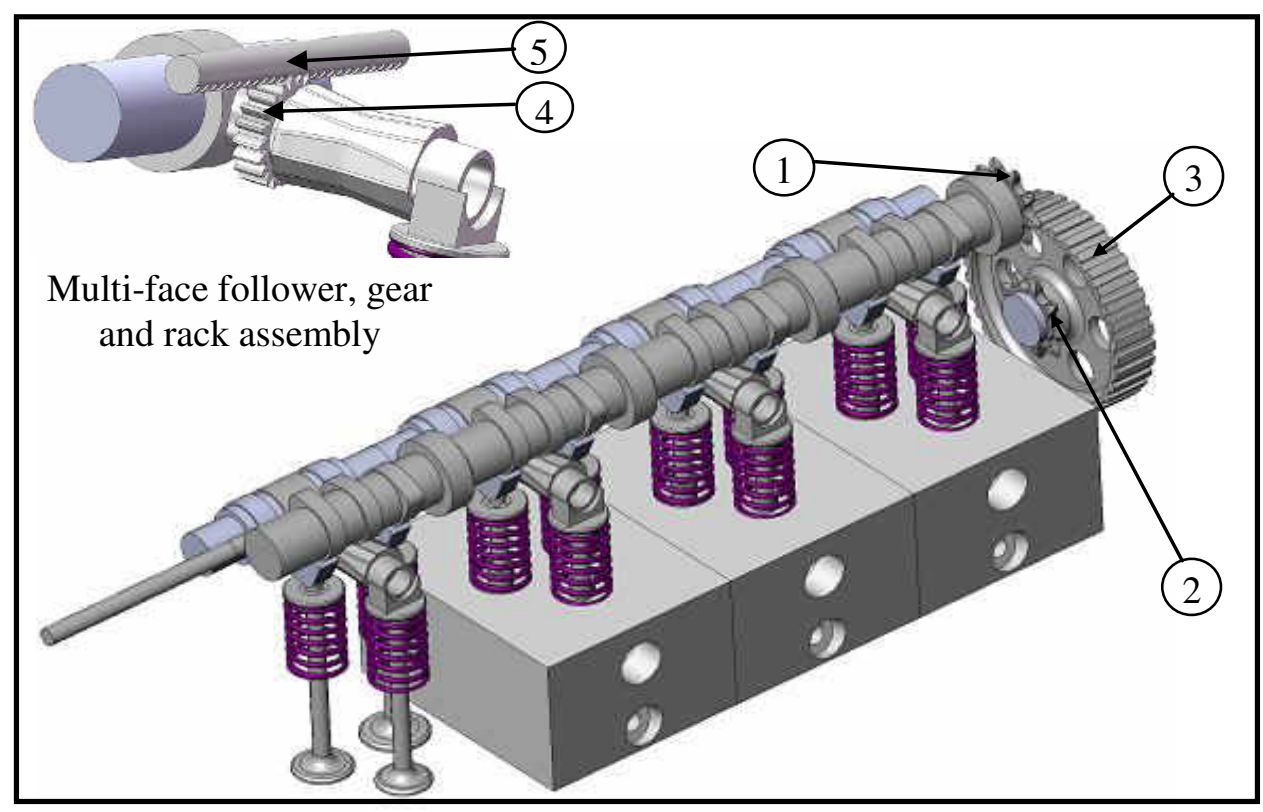

Fig. 33 Complete assembly of the VVT mechanism

\section{GENERAL CONCLUSION}

From conclusions in sections $\mathbf{6 . 3}$ and $\mathbf{7 . 1}$ it is obvious that the new strategy achieves significant improvement to the engine performance more than that achieved by the other four strategies discussed in the introduction.

\section{REFRENCES}

1. Sellnau, M. and Rask, E. "Two-Step Variable Valve Actuation for Fuel Economy, Emissions, and Performance" SAE Technical Paper Series 2003-01-0029, March, 2003.

2. Jason, M. "Engine Modeling of an Internal Combustion Engine With Twin Independent Cam Phasing" Ph.D. Thesis, Ohio State University, 2007.

3. Stone, R. "Introduction to Internal Combustion Engines" MACMILLAN PRESS LTD, 1999.

4. Saunders, R. J. and Rabia, S. M. "Part Load Efficiency in Gasoline Engines" Proceedings of IMechE Seminar on Practical limits of Efficiency in Engines, 1986.

5. Blakey, S. C., Saunders, R. J., Ma, T. H. and Chorpa, A. A. "Design and Experimental study of an Otto-Atkinson Cycle Engine Using Late Intake Valve Closing" SAE paper 910451, 1991.

6. Charlton, S.J. and Shafie-pour, M. "A Continuously Variable Poppet Valve Actuator for Internal Combustion Engine “, Proc. Instn. Mech. Engrs., Vol. 200 No., A3, 1986. 
7. Parker, P. H. et al "The Variable Valve Timing Mechanism for the Rover K16 Engine" Part 1: Selection of the Mechanism and the Basis of the Design, Proc.Instn.Mech.Engrs, Vol.214 Part D, 2000.

8. Parker, P. H. et al "The Variable Valve Timing Mechanism for the Rover K16 Engine" Part 2: Application to the Engine and the Performance Obtained, Proc.Instn.Mech.Engrs, Vol.214 Part D, 2000.

9. Sellnau, M. and Rask, E. "Two-Step Variable Valve Actuation for Fuel Economy, Emissions, and Performance" SAE Technical Paper Series 2003-01-0029, March, 2003.

10.Otto, E., Rubbert, S. and Borrmeister, J. "Thermodynamics and Charge Exchange of the New BMW Six-Cylinder Engine" Proc. Instn. Mech. Engrs. Vol. 214, 2000.

11.Ahmed, S.A., Ibrahim, A. M., Wasef, F. M., Selim, H."Influence Of Auxiliary Exhaust Valve With Variable Timing On Spark Ignition Engine Performance"

12.fluent user guide. http://www.cfd-online.com/Forum/news.cgi/read/3326. $10 / 9 / 2009$.

13.Heyood, J. B."Internal Combustion Engine Fundamentals", First Edition, McGRAW-HILL International Edition, 1988.

14.Verozicoo, R., Mohd-Yusof, J., Orlandi, P. and Haworth, D. "LES in Complex Geometries Using Boundary Body Forces", Center of turbulence research, 1988.

15. Bicen, A. F., Vafidis, C. and Whitelaw, J. H."Steady and Unsteady Air Flow Through The Intake Valve of a Reciprocating Engine", Journal of Fluids Engineering, Vol. 107/413, Sept., 1985

16. http://performancetrends.com/tumble_fixture.htm. 10/9/2009

17.http://www.autozine.org/technical_school/engine/petrol1.htm. 10/9/2009

\section{تاثيروجود صمام سحب ثانوي ذو توقيت متغير على أداء محرك البنزين}

تم استخدام طريقة جديدة لتغيير توقيت الصمامات تعتمد على اضافة صمام سحب ثانوي يتم التحكم فيه بميكانزم صمم خصيصا لذلك. والبحث الحالي يمثل دراسة عملية ونظرية لتطبيق هذه الطريقة

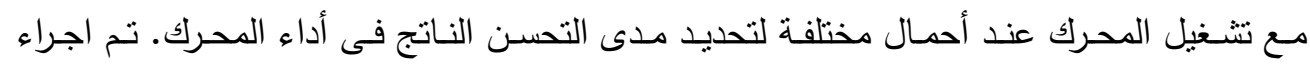

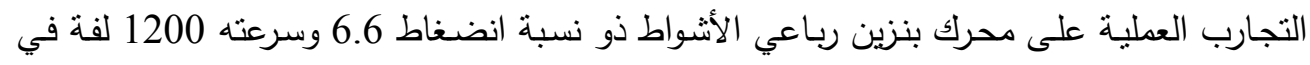

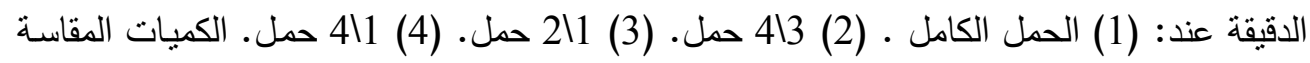
أثناء التجارب هى معدل سريان الهواء خلال صمامى السحب الرئيسى والثانوى، معدل سريان الوقود خلال نفس الصمامين، القدرة الفرملية، القدرة الاحتكاكية. كما تم حساب نسبة الغازات المتنقية داخل الاسطوانة وانبعاثات غاز أول اكسيد الكربون وأكاسيد النيتروجين والهيدروكربون من خـالال نمـنج محاكي أحادي البعد. تم حسـاب نسبة الدوامـة الأفقية (Swirl ratio) و نسبة الدوامـة الرأسبية 
ونوزيع نسبة التكافؤ داخل الاسطوانة من خلال نموذج محاكى ثلاثى. أظهرت (Tumble ratio) النتائج العملية والنظرية نسب التحسن في أداء الدحرك كالتالي: 1. الحمـل الكامـل ذادت القدرة الفرمليـة بمقدار 10.34 \% و و الكفـاءة الحراريــة الفرمليـة بمقدار 16.76 \% و كتلة الثحنة الطازجة بمقدار 6.7 \% و الكفاءة الحجمية بمقدار 10.1 \% \% و وقلت

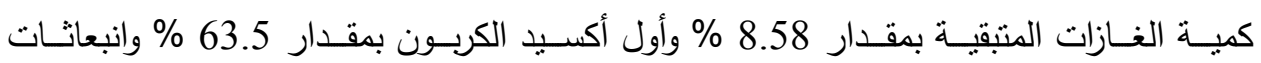

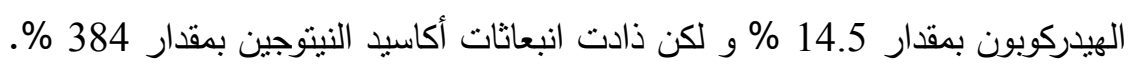

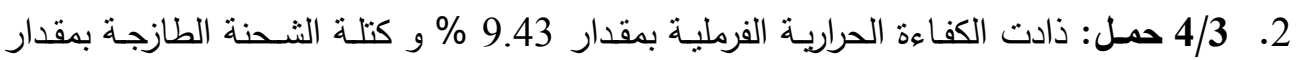

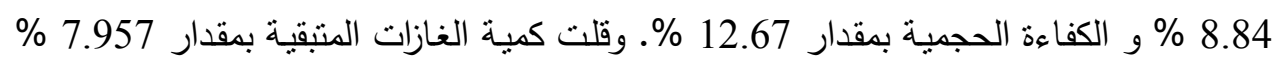
وأول أكسـبد الكربـون بمقدار 9.84 \% و وانبعاثـات الهيـدركوبون بمقدار 14.8 \% و و لكـن ذادت انبعاثات أكاسيد النيتوجين بمقدار 305 \%.

3. 2/1 حمل: ذادت الكفاءة الحرارية الفرملية بمقدار 6.38 \% وكتلة الثحنة الطازجة بمقدار 14.9 و الكفاءة الحجمية بمقدار 19.44 \% و وقلت كمية الغازات المتنقية بمقدار 14.67 \% 14.6. الهيدركوبون بمقدار 18.66 \% و انبعاثات أكاسيد النيتوجين بمقدار 5.12 \% 19.12 و

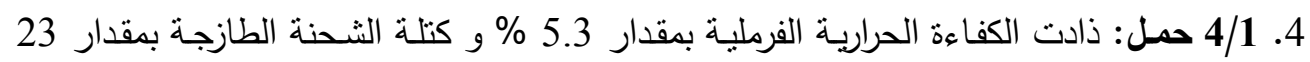

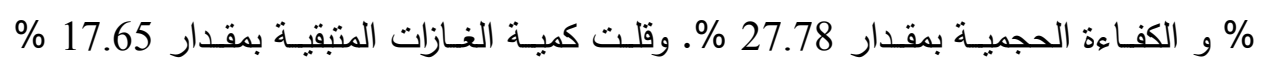
وانبعاثات الهيدركوبون بمقدار 3.3 \% و انبعاثات أكاسيد النيتوجين بمقدار 82.5 \% و 87.5 \% من خلال النموذج ثلاثي الأبعاد تبين أن وجود صمام ثانوي يقلل نسبتي الدوامة الأفقية و الرأسية

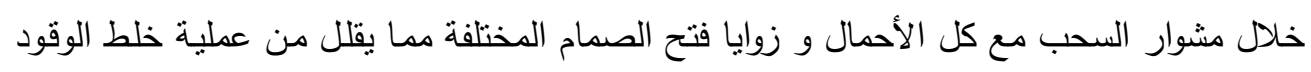

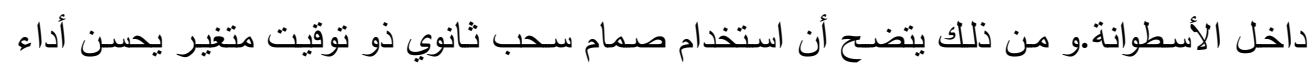

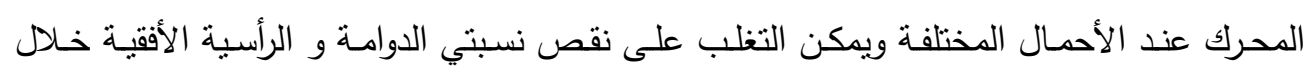

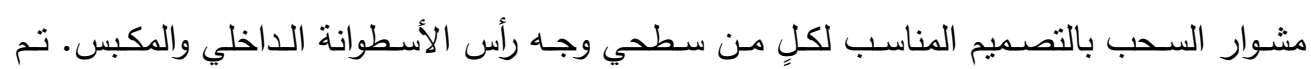

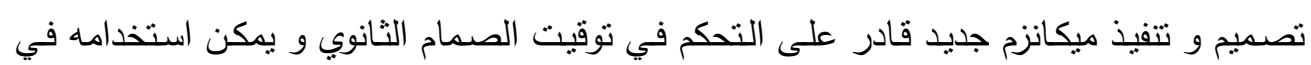
التطبيقات العملية للمحركات. 